p-ISSN: 2503-1228; e-ISSN: 2621-4172

\title{
PENERAPAN METODE DEMONSTRASI UNTUK MENINGKATKAN \\ KEMAMPUAN GURU DALAM MENGGUNAKAN MICROSOFT OFFICE \\ POWER POINT SEBAGAI MEDIA PEMBELAJARAN \\ DI SMPN 1 SUKORAME LAMONGAN \\ SEMESTER GANJIL TAHUN PELAJARAN 2019/2020
}

\author{
Sulkan \\ SMP Negeri 1 Sukorame Lamongan \\ Email : ansulkan@gmail.com
}

\begin{abstract}
Abstrak :
Proses pembelajaran yang dilaksanakan di SMPN 1 Sukorame Lamongan dinilai masih belum memanfaatkan teknologi yang disediakan sekolah untuk menunjang pendidikan, terutama dalam mata pelajaran tertentu. Hal ini disebabkan para guru mata pelajaran masih belum mengerti seluk beluk media pembelajaran yang akan dimanfaatkan. Untuk meningkatkan kualitas pendidikan di SMPN 1 Sukorame Lamongan diperlukan sebuah pelatihan untuk membantu meningkatkan kemampuan guru di SMPN 1 Sukorame Lamongan khususnya dalam aspek pengajaran. Penerapan metode Demonstrasi dimulai dengan peneliti menjelaskan materi menggunakan media Microsoft Office Power Point sebagai media demonstrasi dan memperagakannya. Kemudian, peserta membentuk kelompok untuk berdiskusi mengerjakan tugas. Setelah tugas selesai, kelompok mendemonstrasikan tugas yang telah diberikan. Keberhasilan peningkatan kemampuan peserta penelitian pada penelitian ini adalah seluruh peserta mendapatkan nilai tugas membuat slide presentasi dengan $75 \%$ peserta pelatihan tuntas KKM dengan nilai Baik atau Sangat Baik. Pada siklus I terdapat 50\% peserta yang sesuai dengan indikator keberhasilan. Pada siklus II $100 \%$ atau seluruh peserta sesuai dengan indikator keberhasilan. Dengan demikian, metode demonstrasi mampu meningkatkan kemampuan peserta dalam menggunakan Microsoft Office Power Point sebagai media pembelajaran di SMPN 1 Sukorame Lamongan tahun pelajaran 2019/2020.
\end{abstract}

Kata kunci : Metode Demonstrasi, Microsoft Office Power Point, Media Pembelajaran

\section{PENDAHULUAN}

Salah satu pendidikan yang diajarkan kepada manusia adalah pendidikan sekolah. Pendidikan sekolah diharapkan bisa mensosialisasikan kepada anak- anak didiknya guna menerima perbedaan prestise, privilise, serta status yang ada dalam masyarakat. Dalam praktek pendidikan, baik di lingkungan keluarga, di sekolah maupun di masyarakat 
luas, banyak sekali tujuan pendidikan yang diinginkan oleh pendidik agar dapat dicapai (dimiliki) oleh peserta didiknya. Tujuan pendidikan memuat gambaran tentang nilai-nilai yang baik, luhur, pantas, benar dan indah untuk kehidupan. Karena itu tujuan pendidikan memiliki dua fungsi yaitu memberikan arah kepada segenap kegiatan pendidikan dan merupakan sesuatu yang ingin dicapai oleh segenap kegiatan pendidikan

Dalam sebuah pendidikan pasti terdapat seorang pendidik dan peserta didik. Dalam proses pembelajaran diharapkan peserta didik aktif untuk terus belajar sesuatu yang baru. Dikatakan kelas aktif apabila ada yang mengajukan pertanyaan-pertanyaan berkaitan dengan materi yang diajarkan. Peserta didik akan sangat banyak mengajukan pertanyaanpertanyaan. Hal ini terjadi karena peserta didik melakukan proses berpikir di dalam benaknya. Hasil-hasil pemikiran peserta didik seringkali memerlukan tanggapan dari guru, atau bisa juga peserta didik merasa ada hal-hal yang menjadi kurang jelas dengan apa yang sedang dipelajarinya, atau ada hal-hal yang bertentangan dengan apa yang selama ini diketahuinya. Hal tersebut merupakan sebuah tantangan bagi guru untuk lebih memperluas wawasan yang dimiliki sesuai standart kompetensi guru.

Kompetensi merupakan sebuah penguasaan terhadap aspek pengetahuan, keterampilan dan sikap kerja dalam suatu pekerjaan. Sehingga kompetensi yang dimiliki oleh setiap pendidik atau guru akan menunjukkan kualitasnya sebagai guru yang profesional. Guru harus menguasai materi pembelajaran secara mendalam dan luas. Tidak hanya penguasaan materi pelajaran saja, namun juga penguasaan terhadap materi-materi kurikulum yang berlaku, konsep, struktur keilmuan, serta pengembangan media pembelajaran pada materi yang bersangkutan.

Mata pelajaran berbasis pada pemanfaatan Microsoft Office Power Point di SMP di beberapa kota sudah dimasukkan ke dalam model pembelajaran dan sekarang SMP di seluruh Indonesia pun mulai memanfaatkan dan menggunakan Microsoft Office Power Point ke dalam metode pembelajaran di sekolah. Pemanfaatan Microsoft Office Power Point pada metode pembelajaran di sekolah merupakan inovasi baru di kalangan peserta didik SMP. Inovasi teknologi dalam pendidikan harus memanfaatkan Microsoft Office Power Point di metode pembelajaran, sehingga pembelajaran di SMP dapat disandingkan dengan kemajuan teknologi dan menunjang proses pembelajaran dengan memasukkan teknologi di pembelajarannya, terutama menggunakan Microsoft Office Power Point sebagai media yang mudah digunakan.

Proses pembelajaran yang dilaksanakan di SMPN 1 Sukorame Lamongan dinilai masih belum memanfaatkan teknologi yang disediakan unsur setiap sekolah untuk menunjang pendidikan, terutama dalam mata pelajaran 
tertentu. Hal ini disebabkan para guru mata pelajaran masih belum mengerti seluk beluk media pembelajaran yang akan dimanfaatkan. Untuk meningkatkan kualitas pendidikan di SMPN 1 Sukorame Lamongan diperlukan sebuah pelatihan untuk membantu meningkatkan kemampuan guru di SMPN 1 Sukorame Lamongan khususnya dalam aspek pengajaran. Salah satu metode yang dapat diterapkan dalam rangka pemberdayaan guru adalah metode Demonstrasi. Para guru secara langsung ditunjukkan cara penggunaan media pembelajaran Microsoft Office Power Point, diharapkan mampu mempermudah guru dalam memahami dan mempraktekkan menggunakan media pembelajaran Microsoft Office Power Point.

Berdasarkan latar belakang di atas, peneliti akan melakukan penelitian tindakan sekolah yang berjudul "Penerapan Metode Demonstrasi untuk Meningkatkan kemampuan Guru dalam Menggunakan Microsoft Office Power Point sebagai Media Pembelajaran di SMPN 1 Sukorame Lamongan Semester Ganjil Tahun Pelajaran 2019/2020".

\section{METODE}

Penelitian ini merupakan penelitian tindakan. Penelitian tindakan merupakan bentuk untuk mendapatkan pengetahuan tentang perubahan (changes) dan peningkatan (improvement) karena dampak suatu tindakan yang mampu memberdayakan kelompok sasaran. Penelitian tindakan merupakan salah satu cara yang cukup sigmfikan untuk menemukan pengetahuan baru karena target akhir penelitian tindakan tidak membuktikan suatu hipotesis tetapi menghasilkan hipotesis (Pardjono dkk, 2007: 10).

Penyelenggaraan penelitian dilaksanakan dalam beberapa siklus, proses pembelajaran pada masing-masing siklus dikenai perlakuan yang sama (langkah-langkah kegiatan yang sama), yakni terdiri dari empat tahapan dasar yang saling terkait dan berkesinambungan yaitu: (1) perencanaan, (2) pelaksanaan, (3) pengamatan, dan (4) refleksi.

Tahapan kerja pada siklus II memiliki tahapan yang sama dengan kerja siklus I. Pada siklus II, rencana tindakan disusun berdasarkan hasil refleksi siklus I. Kegiatan-kegiatan yang dilakukan pada siklus II dimaksudkan untuk menyempumakan atau memperbaiki pelaksanaan pelatihan pada siklus I. Penelitian ini akan dilanjutkan ke siklus berikutnya sesuai dengan prosedur penelitian yang telah ditetapkan

Sasaran penelitian ini adalah guru di SMPN 1 Sukorame Lamongan tahun pelajaran 2019/2020 yang terpilih berdasar pada hasil wawancara internal peneliti. Berdasarkan hasil wawancara, subjek penelitian berjumlah enam orang guru yang terdiri dari tiga guru laki-laki dan tiga orang guru perempuan..

Instrumen yang digunakan dalam penelitian ini terdiri dari lembar observasi, lembar angket penilaian tingkat kemampuan peserta, alat-alat dokumenter, 
lembar/materi interview atau wawancara dan alat-alat pendukung lainnya.

Jenis Data yang diperoleh dalam penelitian ini adalah data kualitatif dan data kuantitatif yang terdiri dari (1) data hasil penilaian keahlian peserta penelitian dalam mengoperasikan Microsoft Office Power Point dan (2) data hasil observasi

Metode pengumpulan data yang diperlukan dalam penelitian ini menggunakan (1) metode observasi dengan cara melakukan pengamatan dan pencatatan lapangan mengenai proses kegiatan penelitian, (2) metode dokumentasi, yaitu teknik mengambil data dengan memeriksa dokumen yang telah ada sebelum penelitian berlangsung. Teknik dokumentasi sering dilakukan dengan melakukan pencatatan terhadap data yang ditemukan dalam suatu dokumen (Suharto, 2013: 28).

Analisis data hasil penelitian ini menggunakan teknik observasi. Analisis data merupakan cara menyusun dan mengolah data yang dikumpulkan, sehingga menghasilkan kesimpulan yang dapat dipertanggungjawabkan. Analisis data observasi yang digunakan dalam penelitian ini adalah analisis deskriptif kualitatif yaitu berusaha memaparkan data yang diperoleh dari hasil pelaksanaan tindakan yang mencakup proses dan dampak yang terjadi dari suatu siklus secara keseluruhan, selanjutnya dilakukan refleksi untuk mengkaji apa yang telah dihasilkan atau yang belum berhasil dituntaskan dengan tindakan yang telah dilakukan. Bentuk- bentuk analisis data observasi dalam penelitian ini meliputi :

a. Analisis Data Observasi terhadap Peneliti

Langkah untuk menganalisis data observasi terhadap kinelja peneliti saat proses penelitian adalah:

1) Mengubah skor kualitatif menjadi skor kuantitatif dengan menggunakan tabel 2 .

Tabel 2. Perbandingan nilai kualitatif dan kuantitatif

\begin{tabular}{|l|c|}
\hline \multicolumn{1}{|c|}{ Nilai Kualitatif } & Nilai Kuantitatif \\
\hline Sangat Baik & 5 \\
\hline Baik & 4 \\
\hline Cukup & 3 \\
\hline Kurang & 2 \\
\hline Sangat Kurang & 1 \\
\hline
\end{tabular}

2) Menentukan skor perolehan total

3) Menentukan skor maksimal, yaitu $5 \times$ jumlah soal

4) Menentukan nilai akhir dengan rumus:

Nilai Kinerja Penelitian $=$

$$
\frac{\sum \text { skor perolehan } \times 100 \%}{\sum \text { skor maksimum }}
$$

5) Mencocokkan nilai akhir data dengan tabel 3.

Tabel 3 Klasifikasi data kuantitatif

\begin{tabular}{|c|c|c|l|}
\hline No & $\begin{array}{c}\text { Presentase } \\
(\%)\end{array}$ & Nilai & \multicolumn{1}{|c|}{ Kategori } \\
\hline 1 & $90-100$ & A & Sangat Baik \\
\hline 2 & $75-89$ & B & Baik \\
\hline 3 & $60-74$ & C & Cukup \\
\hline
\end{tabular}


p-ISSN: 2503-1228; e-ISSN: 2621-4172

\begin{tabular}{|c|c|c|l|}
\hline 4 & $50-59$ & D & Kurang Baik \\
\hline 5 & $0-49$ & E & $\begin{array}{l}\text { Sangat } \\
\text { Kurang }\end{array}$ \\
\hline
\end{tabular}

b. Analisis Data Observasi Peserta Penelitian

Langkah untuk menganalisis data observasi terhadap aktivitas peserta penelitian saat proses penelitian adalah:

1) Menjumlahkan nilai observasi tiap peserta

2) Menjumlahkan total nilai observasi peserta dalam satu siklus

3) Menentukan nilai rata-rata peserta dengan cara:

Nilai rata-rata peserta $=$
$\frac{\sum \text { nilai observasi seluruh peserta }}{\sum \text { skor maksimum } \times \sum \text { peserta }} \times 100 \%$
Nilai rata-rata peserta $=$
$\sum$ nilai observasi seluruh peserta
$15 \times 6$

4) Mencocokkan nilai rata-rata peserta dengan tabel 2.

c. Analisis Hasil Penilaian Tingkat Kemampuan Peserta

Hasil evaluasi penilaian tingkat kemampuan peserta ini digunakan untuk mengukur seberapa efektif metode Demonstrasi terhadap proses pembelajaran untuk meningkatkan kemampuan peserta penelitian dalam menggunakan Aplikasi Microsoft Office Power Point. Hasilnya dianalisis dari pencapaian nilai yang diperoleh peserta.
Langkah analisis tugas peserta penelitian adalah:

1) Memberikan nilai untuk setiap aspek materi yang ditunj ukkan dengan tanda $(X)$, dengan cara:

a) Nilai 5 jika memilih Option jawaban SB (Sangat Baik)

b) Nilai 4 jika memilih Option jawaban B (Baik)

c) Nilai 3 jika memilih Option jawaban C (Cukup)

d) Nilai 2 jika memilih option jawaban $\mathrm{K}$ (Kurang)

e) Nilai 2 jika memilih option jawaban SK (Sangat Kurang)

2) Menjumlahkan skor yang didapat setiap peserta dan' semua aspek penilaian.

3) Menentukan nilai akhir tiap peserta dengan rumus:

$$
\begin{aligned}
& \text { Nilai rata-rata peserta }= \\
& \sum \text { Skor yang didapat X } 100 \\
& \sum \text { Skor maksimal }
\end{aligned}
$$

Untuk menganalisis hasil ulangan harian ini digunakan analisis kuantitatif, sebagai berikut :

\begin{tabular}{c}
$\begin{array}{c}\% \text { Kemampuan peserta }= \\
\sum \text { peserta yang lulus KKM } \\
\sum \text { seluruh peserta }\end{array}$ \\
\hline
\end{tabular}

\section{Indikator Keberhasilan}

Indikator keberhasilan dalam penelitian ini adalah $75 \%$ peserta penelitian memenuhi standar kriteria keahlian menggunakan aplikasi Microsoft 
Office Power Point, mendapat kriteria baik atau sangat baik

\section{PEMBAHASAN}

Penelitian ini merupakan penelitian tindakan sekolah yang bertujuan untuk meningkatkan kemampuan Guru dalam menggunakan Microsoft Office Power Point sebagai media pembelajaran di SMPN 1 Sukorame Lamongan semester ganjil tahun pelajaran 2019/2020.

\section{Hasil Observasi Terhadap Peneliti}

Di setiap siklus tindakan, observer selalu mengisi lembar observasi untuk menilai kinerja peneliti di kelas. Pada beberapa tabel di atas telah dipaparkan data hasil observasi yang dilakukan observer. Pada tabel 1 terlihat data keseluruhan hasil observasi terhadap peneliti pada siklus I dan II.

Tabel 1. Data observasi terhadap peneliti pada siklus I dan siklus II

\begin{tabular}{|c|c|c|c|c|c|c|c|c|c|c|c|}
\hline \multirow[t]{3}{*}{ No } & \multirow{3}{*}{$\begin{array}{c}\text { Aspek } \\
\text { Pengamatan }\end{array}$} & \multicolumn{10}{|c|}{ Hasil Pengamatan } \\
\hline & & \multicolumn{5}{|c|}{ Siklus I } & \multicolumn{5}{|c|}{ Siklus II } \\
\hline & & $\begin{array}{l}\text { SB } \\
\text { (5) }\end{array}$ & $\begin{array}{l}\text { B } \\
(4)\end{array}$ & $\begin{array}{l}\mathrm{C} \\
\text { (3) }\end{array}$ & $\begin{array}{l}\mathrm{K} \\
\text { (2) }\end{array}$ & $\begin{array}{l}\text { KS } \\
\text { (1) }\end{array}$ & $\begin{array}{l}\text { SB } \\
(5)\end{array}$ & $\begin{array}{c}\text { B } \\
\text { (4) }\end{array}$ & $\begin{array}{l}\mathrm{C} \\
\text { (3) }\end{array}$ & $\begin{array}{l}K \\
(2)\end{array}$ & $\begin{array}{l}\text { KS } \\
\text { (1) }\end{array}$ \\
\hline 1 & $\begin{array}{l}\text { Penggunaan } \\
\text { Pendekatan }\end{array}$ & & $\mathrm{x}$ & & & & $X$ & & & & \\
\hline 2 & $\begin{array}{l}\text { Alokasi } \\
\text { Waktu }\end{array}$ & & $\bar{x}$ & & & & & $x$ & & & \\
\hline 3 & $\begin{array}{l}\text { Membimbing } \\
\text { Peserta }\end{array}$ & & & $\mathrm{x}$ & & & & $x$ & & & \\
\hline 4 & $\begin{array}{l}\text { Kejelasan } \\
\text { Penugasan }\end{array}$ & & $x$ & & & & & $x$ & & & \\
\hline 5 & $\begin{array}{l}\text { Mengevaluasi } \\
\text { hasil kegiatan } \\
\text { peserta }\end{array}$ & & $x$ & & & & $x$ & & & & \\
\hline 6 & $\begin{array}{l}\text { Mendorong } \\
\text { peserta } \\
\text { mencari data } \\
\text { informasi } \\
\text { untuk } \\
\text { menjawab } \\
\text { pertanyaan }\end{array}$ & & & $x$ & & & & $x$ & & & \\
\hline 7 & $\begin{array}{l}\text { Mendorong } \\
\text { peserta } \\
\text { berpikir } \\
\text { kreatif dan } \\
\text { aktif }\end{array}$ & & $x$ & & & & & $x$ & & & \\
\hline
\end{tabular}

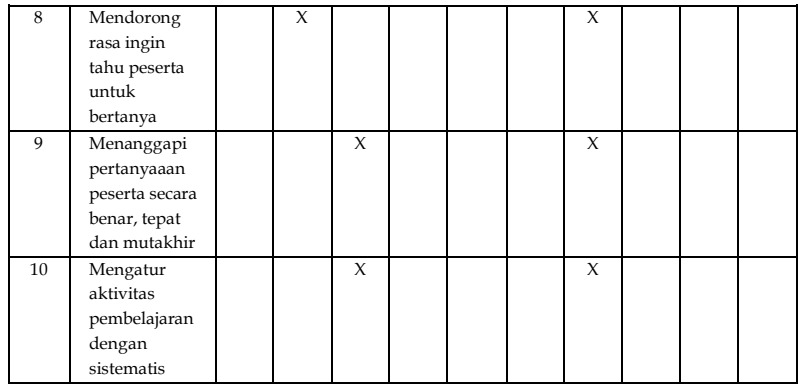

Berdasarkan tabel 1 dapat terlihat dari ke10 aspek yang diamati oleh observer terhadap guru maka presentase nilai yang di dapat guru adalah :

Siklus I

$=\underline{4+4+3+4+4+3+4+4+3+3} \times 100 \%=72 \%$ 50

Siklus II

$$
=\frac{5+4+4+4+5+4+4+4+4+4}{50} \times 100 \%=84 \%
$$

Dengan demikian, pada siklus I dengan pencapaian $72 \%$, maka penilaian kinerja peneliti termasuk ke dalam klasifikasi $\mathrm{C}$ (Cukup). Sedangkan pada siklus II dengan pencapaian $84 \%$, maka penilaian kinerja peneliti termasuk ke dalam klasifikasi B (Baik). Hal tersebut menunjukkan bahwa kinerja peneliti semakin meningkat dalam proses pelatihan di siklus Penelitian Tindakan Sekolah ini.

\section{Analisis Hasil Observasi Terhadap} Peserta Penelitian

Aktivitas peserta dalam setiap siklus terus diamati oleh observer untuk melihat secara fisik tentang perkembangan yang terjadi. Hasil keseluruhan observasi terhadap peserta dapat dilihat pada tabel 2 berikut. 
Tabel 2. Data observasi terhadap Peserta

\begin{tabular}{|c|l|c|c|}
\hline No & \multicolumn{1}{|c|}{ Nama } & \multicolumn{2}{|c|}{$\begin{array}{c}\text { Nilai } \\
\text { (Minat, Perhatian, } \\
\text { Kerjasama) }\end{array}$} \\
\cline { 3 - 4 } & & Siklus I & Siklus II \\
\hline 1 & Peserta I & 11 & 12 \\
\hline 2 & Peserta II & 11 & 11 \\
\hline 3 & Peserta III & 12 & 12 \\
\hline 4 & Peserta IV & 10 & 11 \\
\hline 5 & Peserta V & 11 & 12 \\
\hline 6 & Peserta VI & 10 & 14 \\
\hline \multicolumn{2}{|c|}{ Total Nilai } & 65 & 72 \\
\hline \multicolumn{2}{|c|}{ Persentase } & $72,2 \%$ & $80 \%$ \\
\hline
\end{tabular}

Pada Siklus I nilai rata-rata yang didapat peserta adalah :

$$
72,2 \%=\frac{65}{15 \times 6} \times 100 \%
$$

Sedangkan pada siklus II nilai ratarata yang di dapat peserta adalah :

$$
72,2 \%=\frac{72}{15 \times 6} \times 100 \%
$$

Dengan demikian mengacu pada tabel 2, maka pada siklus I nilai rata-rata peserta 72,2\% masuk dalam kategori C (Cukup). Sedangkan nilai rata-rata peserta pada siklus 11, yaitu $80 \%$, masuk dalam kategori B (Baik). Hasil penelitian memperlihatkan bahwa nilai rata-rata aktivitas peserta saat penelitian berlangsung menunjukkan adanya peningkatan.

\section{Hasil dan Analisis Tugas Peserta}

Analisis ini dilakukan untuk menjawab tujuan penelitian, yaitu meningkatkan kemampuan peserta penelitian dalam membuat slide power point dengan menggunakan metode Demonstrasi tahun pelajaran 2019/2020.

Dengan analisis ini akan diketahui apakah terjadi peningkatan kemampuan peserta penelitian di setiap siklus PTS atau tidak, dengan cara membandingkan dengan nilai hasil tugas. Indikator keberhasilan dari penelitian ini adalah $75 \%$ peserta penelitian memenuhi standar kriteria "Baik" atau "Sangat Baik" pada keahlian menggunakan aplikasi Microsoft Office Power Point.

Tabel 3. Hasil Penilaian Tugas Peserta

\begin{tabular}{|c|c|c|}
\hline \multirow{2}{*}{ Siklus } & \multicolumn{2}{|c|}{$\begin{array}{c}\text { Peserta dengan kriteria } \\
\text { Baik/Sangat Baik }\end{array}$} \\
\cline { 2 - 3 } & Jumlah & $\%$ \\
\hline 1 & 3 & 50 \\
\hline 2 & 6 & 100 \\
\hline
\end{tabular}

Tabel 3 memperlihatkan kenaikan jumlah guru yang mencapai ketuntasan minimal (data lengkap lihat lampiran) di setiap siklus. Pada siklus 1 terdapat 50\% (3 peserta) melebihi indikator keberhasilan. Pada siklus II terdapat 100\% (6 peserta) melebihi indikator keberhasilan. Data tersebut memperlihatkan teijadi peningkatan dari siklus I sampai siklus 11. Dan keberhasilan penelitian sesuai dengan indikator keberhasilan didapat saat siklus II, yaitu $100 \%$ peserta memiliki kriteria baik atau sangat baik.

Untuk mengetahui secara jelas perubahan hasil penelitian selama silkus I dan siklus II sebagaimana tersebut di atas, maka 
data-data tersebut kami sajikan dalam bentuk grafik berikut:

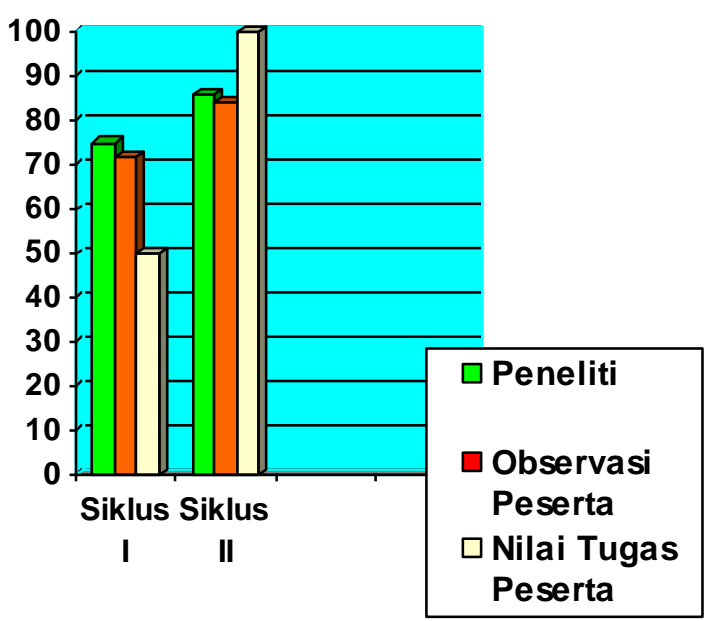

Berdasarkan hasil penelitian sebagaimana perolehan data-data di atas, maka dapat dikatakan bahwa penggunaan metode demonstrasi berhasil meningkatkan kemampuan guru dalam menggunakan aplikasi Microsoft Office Power Point sebagai media pembelajaran di SMPN 1 Sukorame Lamongan semester ganjil tahun pelajaran 2019/2020.

\section{KESIMPULAN}

Dari hasil serangkaian analisis data dan pembahasannya, maka dapat diambil satu kesimpulan bahwa penerapan metode demonstrasi dapat meningkatkan kemampuan Guru dalam menggunakan Microsoft Office Power Point sebagai media pembelajaran di SMPN 1 Sukorame Lamongan semester ganjil tahun pelajaran 2019/2020.

\section{DAFTAR PUSTAKA}

AH Sanaky Hujair. 2011. Media Pembelajara Buku Pegangan Wajib Guru dan.
Dosen. Kaukaba. Yogyakarta: Safnria Insania Press

Aminuddin, Rasyad. 2006. Metode Pembelajaran Pendidikan Agama Islam. Jakarta: Bumi Aksara.

Strauss, Anselm, Juliet Corbin. 2003. Dasar-Dasar Penelitian Kualitatif. Yogyakarta: Pustaka Pelajar.

Daryanto. 2010. Media Pembelajaran. Yogyakarta: Gava Media

--------Panduan Proses Pembelajaran Kreatif dan Inovatif. Jakarta: Publisher Hasibuan dan Mudjiono. 2006. Belajar dan Pembelajaran. Jakarta: PT. Rineka Cipta

Jumaidi. 2011. Pembelajaran Matematika Materi Kesebangunan dengan Menggunakan Multimedia Interaktif. Palembang: Prosiding Seminar Nasional

Nur Hamim, dkk. Bahan Ajar PLPG/Pengawas dalam jabatan 2011. Surabaya: LPTK Fakultas Tarbiyah IAIN Sunan Ampel

Pardjono, dkk. 2007. Panduan Penelitian T indakan Kelas. Lembaga Penelitian UNY: Yogyakarta

Pumomo, Catur Hadi. 2008. Panduan Belajar Otodidak Microsoft Powerpoint 2007. Jakarta: Media Kita

Rusminiati. 2007. Pengembangan Pendidikan Kewarganegaraan SD. Depdiknas. Jakarta.

Sudjana, Nana. 2013. Dasar-Dasar Proses Belajar Mengajar. Sinar Baru Algensindo: Bandung

Suharto Tcguh, V. 2013. Pengantar Metodologi Penelitian dan 
Reforma: Jurnal Pendidikan dan Pembelajaran

Vol.9 No. 2 (2020)

p-ISSN: 2503-1228; e-ISSN: 2621-4172

Pengembangan Instrumen Pengukuran. IKIP PGRI Madiun

Syah Muhibbin. 2006. Psikologi Belajar. Jakarta: PT. Raja Grapindo Persada

Sukardi. 2011. Metodologi Penelitian

Pendidikan $K$ ompetensi dan

Praktiknya. Bumi Aksara: Jakarta. 